\title{
The impact of taxes on the extensive and intensive margins of FDI
}

\author{
Ronald B. Davies ${ }^{1,2,3} \cdot$ Iulia Siedschlag ${ }^{4,5}$ (I) Zuzanna Studnicka ${ }^{1}$ (1)
}

Accepted: 31 October 2020 / Published online: 4 January 2021

(c) Springer Science+Business Media, LLC, part of Springer Nature 2021

\begin{abstract}
It is well documented that foreign investment inflows are deterred by host taxes. What is less clear, however, is the degree to which these aggregate changes are driven by firm choices at the extensive (whether to invest) or intensive (how much to invest) margins. Further, there is little evidence on the way in which these two margins are affected by firm and home-country characteristics. We contribute by examining firm-level cross-border investments during 2007-2015 into Europe from a broad group of home countries at both investment margins. Similar to the existing single-country studies, we find that taxes operate primarily on the extensive margin. Building on those results, we delve further and find significant variation across firms with small investors from high-tax home countries especially sensitive to host taxation.
\end{abstract}

Keywords Foreign direct investment $\cdot$ Taxation · Extensive margin · Intensive margin

JEL Classification F23 $\cdot$ F14 $\cdot$ H25

This research is part of the joint Economic and Social Research Institute and the Department of Finance Research Programme on the Macro-Economy and Taxation. The views expressed in this paper are those of the authors and they should not be regarded as an official position of the Department of Finance. We thank Michael Stimmelmayr and seminar participants at the 2019 Conference on Global Production, Taxes, and Trade, ZEW-Mannheim, Technische Universität Berlin, the 2017 International Institute of Public Finance, the Irish Department of Finance, ETH Zürich, Université de Genève, University of North Carolina Chapel Hill, the 2017 International Tax Policy Forum, and University of Oslo for useful discussions. All errors are our own.

Electronic supplementary material The online version of this article (https://doi.org/10.1007/s1079 7-020-09640-3) contains supplementary material, which is available to authorized users.

Ronald B. Davies

ronbdavies@gmail.com

Extended author information available on the last page of the article 


\section{Introduction}

Given the significant role foreign direct investment (FDI) plays in many countries, there has developed a sizeable literature describing the effects FDI has on economies (both the home and host) as well as the factors influencing the amount of FDI that takes place between countries. In particular, the role of taxes in affecting FDI activity has received a great deal of attention, in no small part because taxes are one of the principal policy instruments that governments use to influence investment. The research into the impact of taxes on FDI overwhelmingly finds a negative effect, i.e., mobile firms avoid high-tax locations. ${ }^{1}$ As de Mooij and Everdeen's (2008) meta-analysis of over 400 sets of estimates summarizes on average the literature finds that a one percentage point increase in the host tax results in a $-3.1 \%$ drop in aggregate FDI. These aggregate changes are naturally the sum of changes at the level of individual investments, changes which include both the decision of where to invest (the extensive margin of investment) and, given that investment occurs, how much to invest (the intensive margin). Compared to the body of work on aggregate FDI changes, however, there is little work investigating how taxes influence these two micro-level margins and how those changes may vary across different firms. This paper contributes by estimating the impact of taxation on the extensive and intensive margins using information on 8219 new greenfield FDI investments into Europe from 2007 to 2015 . We find significantly negative host taxes effects at the extensive margin, that is, whether or not a potential host country receives the investment. Further, we find that this sensitivity is more negative for investors coming from high-tax home countries.

We do not claim to be the first to study the impact of taxes on firm-level decisions. Indeed, the pioneering work of Devereux and Griffith (1998) included host taxes when estimating the location decision for foreign affiliates. Like the large literature following in their footsteps (including the current paper), they found that host taxes have a negative effect on the extensive margin, i.e., FDI is less likely to locate in high-tax hosts. ${ }^{2}$ This work, however, focuses exclusively on the extensive margin. Two studies, however, estimate the impact of taxes at both margins as we do. ${ }^{3}$ The first is Davies et al. (2009) use data on outbound Swedish FDI and find no impact of host taxes on investment at either margin. In contrast, Egger and Merlo (2011) analyze the impact of the host-country tax rates German investments abroad and find a negative effect at both margins. This begs the question of why they find very

\footnotetext{
${ }^{1}$ Given the size of the literature, the surveys of Gresik (2001), Fuest et al. (2005), or Voget (2015) provide useful starting points.

2 Examples include Hebous et al. (2011), Barrios et al. (2012), Merlo et al. (2016), Behrendt and Wamser (2018), Davies and Killeen (2018), and Lawless et al. (2018). Although these studies vary according to the data used (some use data from a single home country, others for several), measurement of taxes (which includes effective taxes, statutory taxes, and the tax difference between the home and host), and methodology (with conditional logit, nested logit, and mixed logit being employed across and within analyses), the consensus is that taxes tend to lower the probability of a firm choosing a potential host.

3 Yeaple (2009) examines both margins using US firm-level data. Davies and Kristjánsdóttir (2010) do so for industry-level Icelandic FDI. Neither controls for taxes.
} 
different conclusions. One possibility is that whereas Sweden's tax is fairly average, the German tax is rather high. Thus, the desire to locate in a low-tax host may differ across these two home countries. ${ }^{4}$ With this in mind, we use data on FDI originating from 40 different home countries. ${ }^{5}$ Further, using a mixed logit estimator, we investigate how the investment-level tax sensitivity varies with the home tax. ${ }^{6}$ Doing so reveals that firms from high-tax homes are more sensitive to host taxes, a result which can help explain the differing results between those two studies. We also find that the host-tax sensitivity varies with firm age and size as well as the GDP of the home country. ${ }^{7}$ If the set of investors differs between Sweden and Germany (and GDP obviously does), then our approach can further reconcile these different findings. Finally, unlike Davies et al. (2009), we control for selection into investment when estimating the role of taxes at the intensive margin (i.e., we control for the fact that, to measure the size of investment, investment must have taken place). ${ }^{8}$ We do not, however, find that this heterogeneity extends to the intensive margin, reinforcing the notion that taxes primarily influence investment at the extensive margin.

That the primary effect is at the decision of whether to invest rather than the size of the investment harkens back to Hartman (1985) who shows that, because of the tax treatment of retained earnings ploughed back into subsidiary expansion, that it is advantageous for an MNE to initially invest at a minimum efficient scale and then grow its foreign affiliate out of the affiliate's profits. ${ }^{9}$ Thus, there may not be sufficient scope for taxes to influence the initial size of affiliates. The value in our results, however, extends beyond providing support for this idea.

One venue in which it matters is in how one might model the welfare implications from tax competition. In the classic models of Wilson (1986) and Zodrow and Mieszkowski (1986), investment operates only at the intensive margin. Conversely, in Haufler and Wooton (1999) the investment decision is solely extensive. Whereas taxes are pushed inefficiently low from the perspective of host countries in both approaches, the first can easily yield inefficient FDI distributions while the latter

\footnotetext{
${ }^{4}$ Indeed, in the literature using aggregate FDI data, the home tax is often a "push" factor, i.e., investment often flees a high-tax home.

${ }^{5}$ Using a single host country, Görg and Strobl (2015) examine the effect of Irish taxation on its inbound FDI at the industry level. On average, they find no effect of taxes at the extensive margin excepting that from Germany. Employment growth, their measure of the intensive margin, is meanwhile hampered by higher Irish taxes, but only for pre-existing firms.

6 A similar approach was used by Behrendt and Wamser (2018) when looking at how firm characteristics influence the effect of bilateral tax treaties on the extensive margin of FDI. Note that unlike Behrendt and Wamser (2018), Egger and Merlo (2011), and Davies et al. (2009), we do not include the existence of a bilateral tax treaty as a control variable. This is because, in our sample of mostly European home and hosts, there is very little variation in the use of treaties.

7 When estimating the extensive margin, Lawless et al. (2018), Merlo et al. (2016), Behrendt and Wamser (2018) and Davies and Killeen (2018) find firm-driven heterogeneous tax responses. They do so via sample splits and/or the use of mixed logit.

8 Note that this avoids the well-known problem of zeros in the $\log -\log$ gravity specification. See Santos Silva and Tenreyro (2006) for discussion.

9 The idea of a minimum efficient scale is now well recognized in the FDI literature as embodied by seminal work such as Helpman et al. (2004).
} 
leads to an efficient location decision. ${ }^{10}$ Recent models of taxation combine these, finding that even with a continuum of firms, the discrete investment decision by individual firms significantly impacts optimal equilibrium taxes, efficiency, and the distribution of surplus. ${ }^{11}$ Thus, recognizing how taxes affect individual FDI decisions has implications for aggregate welfare. Beyond taxation, understanding how tax policy affects the extensive and intensive margins of FDI has welfare implications. For example, it is well known that, beginning with a Cournot equilibrium among imperfectly competitive firms, changing the number of competitors while keeping their cost structures the same is not welfare-equivalent to increasing marginal costs but keeping the number of competitors constant. ${ }^{12}$ Finally, the issue of time is likely very different for extensive and intensive investment decisions. One might suspect that features such as the speed of technology transfer from foreign firms to the local economy depend on whether there are fewer or simply smaller foreign firms. Additionally, one may well anticipate that firm reaction times are much faster at the intensive rather than extensive margin because it may be easier to scale up (or down) an existing affiliate rather than create a new one. As such, when sharp, sudden crises occur (such as the shutdowns engendered by the 2020 emergence of the Covid-19 disease), a country may be better able to respond if investments are present, with their initial size a secondary concern. Thus, recognizing that taxes influence aggregate FDI patterns at the extensive margin is potentially important in developing policies to maximize economic growth and stability.

Section 2 lays out our empirical methodology and describes our data. Section 3 contains our results and a number of robustness checks. Section 4 concludes.

\section{Estimation approach and data}

Our approach to the data is one in which we envision the MNE's investment as a two-step process that first computes the highest after-tax profits that could be earned in a given location and then chooses the most profitable location as the actual host. With this in mind, the firm first determines the after-tax profitability of locating its affiliate in a potential host country $h \in H$ where $H$ is the set of possible hosts. This after-tax profitability is a function $\pi_{o, m, h, t}(K)$ that depends on $K$, the size of the investment. It also is influenced by characteristics of the owner (parent firm) $o$ such as its size or age. It also depends on features of the owner's home country $m$ (such as its tax rate), the host $h$ under consideration (including taxes, GDP, and other variables), and the year of investment $t$. Note that this setup can also include country-pair variables such as distance between the home and potential host. This then yields a profit-maximizing investment choice $K_{o, m, h, t}^{*}$ which, naturally, is only observed if $h$ is

\footnotetext{
${ }^{10}$ This is because in the latter, competition amounts to a second price auction so that the efficient host, which generates the most surplus from investment and therefore offers the highest bid for the firm, hosts in equilibrium.

11 See e.g., Davies and Eckel (2010) or Krautheim and Schmidt-Eisenlohr (2011).

12 See Tirole (1988) for discussion.
} 
chosen as the host for the affiliate. Second, the firm compares the after-tax profits across locations, i.e., how those in $h, \pi_{o, m, h, t}^{*}=\pi_{o, m, h, t}\left(K^{*}\right)$, compared to the level of after-tax profits elsewhere. Following this comparison, the firm chooses the actual location $l \in H$ if $l=\underset{h \in H}{\arg \max } \pi_{o, m, h, t}^{*}$, i.e., if this $l$ results in the highest profit. This setup follows the location choice literature with the simple extension that, in addition to considering the choice of host (the extensive margin), we include that the value of locating in a given host depends on an optimal investment decision (the intensive margin).

\subsection{Estimating location choice}

Traditionally, the empirical method for estimating the choice of host country employs the conditional logit model. Examples include (Head et al. 1995; Crozet et al. 2004; Barrios et al. 2012; Lawless et al. 2018), and many others. This approach specifies the unobserved maximum profit in a location as:

$$
\pi_{o, m, h, t}^{*}=\alpha \mathbf{X}_{o, m, t}+\beta \mathbf{Z}_{m, h, t}+\varepsilon_{o, m, h, t}
$$

In this, $\mathbf{X}_{o, m, t}$ is a vector of variables that vary by owner (such as firm size), home country (such as the home tax rate), and/or time (including year-specific effects) but not by host $h .{ }^{13}$ Note that these control variables do not vary by host, with those variables being found in $\mathbf{Z}_{m, h, t}$. Again this can include factors that vary just by host as well as those that vary by the home and host (such as distance between them or the difference between the home and host tax rates). The final term, $\varepsilon_{o, m, h, t}$, is a disturbance term (following the iid extreme value distribution). Given this error distribution, the probability that a given host $l$ is chosen is:

$$
\operatorname{Pr}_{o, l, m, t}=\frac{\exp \left(\alpha \mathbf{X}_{o, m, t}+\beta \mathbf{Z}_{m, l, t}\right)}{\sum_{h \in H} \exp \left(\alpha \mathbf{X}_{o, m, t}+\beta \mathbf{Z}_{m, h, t}\right)}
$$

which reduces to the familiar:

$$
\operatorname{Pr}_{o, m, l, t}=\frac{\exp \left(\beta \mathbf{Z}_{m, l, t}\right)}{\sum_{h \in H} \exp \left(\beta \mathbf{Z}_{m, h, t}\right)}
$$

This approach has several key features. First, consistent with the above formulation of the investment decision, it is based on a decision process in which the investment's owner compares affiliate profitability across locations. Thus, the probability here is that $l$ is chosen as the host instead of some alternative location and the unobserved profits for different alternatives are not correlated (giving rise to the irrelevance of independent alternative (IIA) property). Second, we follow the bulk of the existing literature and take the year of investment as given, that is, this choice

\footnotetext{
13 In the original random utility model of McFadden (1974) on which logit estimators were based, a representative agent was assumed so that there was no variation by, for example, owner or home country.
} 
is across locations only and not across time. Third, because host-invariant variables fall out of the probability function, this comparison is based only on differences across hosts. As such, coefficients for home country features such as GDP or the home tax cannot be estimated. Finally, this assumes that the estimated parameters are the same for all investment decisions so that there is no heterogeneity in the tax sensitivity across investments.

In order to relax the assumptions imposed by the conditional logit, recent contributions have employed a mixed logit approach (see McFadden and Train (2000)). ${ }^{14}$ The mixed logit approach allows one to avoid the main limitations of the standard logit model by allowing for random taste variation, unrestricted substitution patterns, and correlation of unobserved factors over time (see McFadden and Train (2000) for a detailed discussion on these advantages).

The mixed logit specification again begins with the profits in a given location:

$$
\pi_{o, m, h, t}^{*}=\alpha_{o} \tau_{h, t}+\beta \mathbf{X}_{o, m, t}+\gamma \mathbf{Z}_{m, h, t}+\varepsilon_{o, m, h, t}
$$

where the only change is that this specifically separates out $\tau_{h, t}$, the tax rate in country $h$, from $\mathbf{Z}_{m, h, t}$. The reason is that, although the parameters in $\gamma$ are fixed population parameters that do not vary by firm, the responsiveness to the host tax given by $\alpha_{o}$ can vary by firm. ${ }^{15}$ Specifically, it is assumed that $\alpha_{o}=\alpha+\mu_{o}$ is a firm-specific random coefficient that has a normal distribution with mean $\alpha$ and a standard deviation $\sigma$. When $\sigma \neq 0$, firms differ in their response to the host tax, generating the "mix" of tax effects giving the estimator its name. ${ }^{16}$

These firm specific tax coefficients can then be compared to one another in a follow-up regression. In particular, one can then examine how variables which are hostinvariant (and therefore cannot be included in estimating the location choice) are correlated with the firm-specific $\alpha_{o}$. To do so, we estimate the following equation:

$$
\alpha_{o}=\alpha+\beta \mathbf{X}_{o, m}+\varepsilon_{o, m}
$$

Note that in this, we use the variables $\mathbf{X}_{o, m}$ for the year of the investment; for firms with multiple investments, we use the sample average for those years in which investment occurred. ${ }^{17}$ Using a similar approach, Behrendt and Wamser (2018) find that while the average effect of the host tax is negative, this effect is less pronounced for large multinationals. We expand on their insights by including additional owner characteristics (size, age, and prior investment activity) and home country variables (including the home tax rate). We do so not only to explore how this is related to owner and other home country characteristics, but also to identify patterns in the

\footnotetext{
14 Examples estimating (only) the extensive location choice include Basile et al. (2008), Merlo et al. (2016), Merz et al. (2017) and Behrendt and Wamser (2018).

15 Note that this is one parameter per owner, not per owner-investment. Thus, for MNEs with multiple investments this is assumed the same across all of their investment projects.

16 Alternatively, $\alpha_{o} \tau_{h, t}$, together with $\varepsilon_{o, m, h, t}$ can be interpreted as error components so that $\mu_{o, h, t}=\alpha_{o} \tau_{h, t}+\varepsilon_{o, m, h, t}$. This creates correlations among the unobserved profits for different location alternatives, relaxing the IIA assumption.

17 Recall that each owner has a single $\alpha o$, hence this approach.
} 
heterogeneity that we can then use to test for heterogeneous tax effects in the intensive margin.

Although our primary results use the mixed logit estimator, we also include conditional logit to ease comparison to the bulk of the existing literature.

\subsection{Estimating the size of investment}

Following the estimation of the extensive margin, we then pair our results with a second-stage estimation of the size of investment:

$$
\ln \left(F D I_{i, o, m, h, t}\right)=\alpha+\beta^{I} \mathbf{X}_{h, t}+\gamma^{I} \mathbf{X}_{m, t}+\delta^{I} \mathbf{X}_{h, m, t}+\zeta^{I} \mathbf{X}_{o, t}+\beta_{M}^{I} M_{i, o, m, h, t}+\varepsilon_{i, o, m, h, t}^{I}
$$

using those observations where investment has occurred in year $t .{ }^{18}$ As controls, we use a typical set of gravity controls that vary by home country, host country, and year as well as owner characteristics, all of which are described below. In addition, using the methodology of Dubin and McFadden (1984), we construct the inverse Mills ratio $M_{i, o, m, h}$ which is then included to control for potential sample selection. ${ }^{19}$ Although this is a nonlinear combination of the host variables, as discussed below, our first stage extensive margin estimation includes two variables that our second stage intensive margin one does not: a measure of fixed cost barriers to investment in the host and the effective average host tax. ${ }^{20}$ In contrast, the intensive margin estimation of (6) uses effective marginal tax rates rather than average rates. Note that this second stage includes host and home fixed effects as well as owner and affiliate sector and year dummies. ${ }^{21}$ Further, we cluster the standard errors in our estimations at the owner-level.

As a final point, note that Eq. 6 is only estimated when investment has occurred, i.e., where the level of FDI is positive. This is different than other estimations of the intensive level of FDI (e.g., bilateral investment activity) where the data are comprised of a large number of zeros since many country pairs have no activity between them. In those cases, taking logs of FDI results in those pairs dropping out of the sample (i.e., selection). Alternatively, as discussed by Santos Silva and Tenreyro (2006), one can use the PPML estimator which retains the no-FDI observations. In

\footnotetext{
18 Note that we include subscripts both for the owner $o$, who may have many affiliates, and an individual affiliate $i$, with this latter identification necessary as the inverse Mills ratio is affiliate specific.

19 In unreported results, as an alternative to our combination of mixed logit and OLS, we also used a Heckman two-step approach where sample selection is estimated as part of a maximum likelihood estimation rather than in a two-step fashion. This is the approach used by Davies and Kristjánsdóttir (2010). As with the reported results, we found significant tax effects only in the first stage which estimated the probability of investment. Note that in our multi-host context, however, this probit-based estimation procedure treats each investment decision as an independent choice, in contrast to the explicit comparison of alternatives as in the logit class of estimators. This is why we use mixed logit in the current results. The results of the Heckman estimator are found in the online appendix.

20 As he used a linear probability model, if Yeaple (2009) included the inverse mills ratio this would amount to including the exclusionary restrictions in the intensive stage.

21 We use two digit sector dummies. Note that we were unable to use sector-year dummies since $51 \%$ of our observations have a single sector-year observation, with a further $20 \%$ having only two.
} 
our case, by using the two-step estimation procedure where we explicitly control for sample selection, we are able to use a log-linear specification when estimating the size of the investment.

\subsection{Data}

Our firm-level data come from Bureau van Dijk's Amadeus (ownership) and Orbis (firm characteristics) datasets to construct a sample of new cross-border investments in Europe. ${ }^{22}$ This database provides several key pieces of information. First, Amadeus indicates the owner of the affiliate, the global ultimate owner's country of residence (the home country), and location of the investment (the host country). Table 1 provides the list of home and host countries along with the share of outbound and inbound investments for the set of firms we use. ${ }^{23}$ We restrict ourselves to crossborder investments, meaning those where the locations of the affiliate and the owner differ. As can be seen, although all of the countries in our data are homes, 12 are not hosts during the sample. This can occur because the Amadeus database does not track those nations' inbound investments or because all of the reported investments in a country were missing the firm-level information used in our regressions. In particular, missing owner information was problematic for certain countries (such as the US and Switzerland), hence the small number of investments originating from them. As an alternative, we repeated our estimation omitting these countries and their $1.8 \%$ of investments, i.e., using an intra-European sample of investments, where we found comparable results. ${ }^{24}$

Second, Amadeus provides the year of the incorporation. To isolate greenfield FDI from M\&A FDI, we examine the location of newly established affiliates in their first year of existence. ${ }^{25}$ We restrict our sample to 2007 to 2015 for consistency purposes, with Table 2 reporting the number of investments in our sample by year. ${ }^{26}$

Third, we use the Orbis dataset to obtain information on the size of the affiliate (measured as total assets in constant 2005 US dollars) during its first year of

\footnotetext{
22 These can be found at http://www.bvdinfo.com.

23 As can be seen, the distribution of home countries reported in Amadeus has some peculiarities. First, the availability of investments from outside of Europe is limited. Second, two small European countries-Belgium and the Netherlands - appear to be potentially overrepresented. One approach for dealing with this is provided by Kalemli-Ozcan et al. (2019). This, however, requires access to vintages of the Amadeus data which we unfortunately lack. Therefore, we instead resort to sub-samples of the data. As reported in the appendix, when restricting our sample to European homes only, we find results quite similar to those reported. The same goes for when we exclude the Netherlands as a home country. When excluding Belgium, the EATR becomes insignificant although the point estimate remains negative. These additional results are in the online appendix.

24 These alternative results are available on request.

25 Thus, we are not considering the wave of corporate inversions via mergers which occurred during the sample period.

${ }^{26}$ Note that there is a decline in investments toward the end of the sample, an issue arising from lagged reporting to the Amadeus data. Excluding 2015 or 2014-2015 has little impact on our results. These alternatives are available in the online appendix.
} 
existence, a measure that serves as our intensive margin. ${ }^{27}$ When a given owner invests multiple times in a given host in a given affiliate sector during the same year, these were added together. In addition, we drop investments where the 2005 US dollar value was under $\$ 1000$ or above $\$ 1$ billion. ${ }^{28}$ Note that the construction of the data set is the same under both methodologies: each investment corresponds to 28 lines of data, one for each potential host, with an affiliate size only available when positive investment occurs.

In addition to affiliate information, Orbis provides information on the owner. This includes the size of the owner, measured as logged total assets in constant 2005 US dollars which is extracted from the unconsolidated statements so as to exclude the affiliate. For an investment that occurs in year $t$, we use the owner size in $t-1$ or, if that is missing, for the closest year for which it was available. We also obtain the age of the owner (i.e., the logged years since its incorporation) and the 2-digit NACE code of the owner and the affiliate. ${ }^{29}$ This leaves us with 8219 investments across 6643 owners for which we have our control variables. In line with Behrendt and Wamser (2018), we anticipate that larger firms have more mechanisms available to minimize tax burdens. We therefore anticipate that size is positively correlated with the estimate of the owner's $\alpha_{o}$, i.e., as size increases, $\alpha_{o}$ becomes less negative meaning that a larger firm is less put off by host taxes at the extensive margin. In addition, we expect that larger and older firms are more likely productive ones and as such, that these increase FDI at the intensive margin, i.e., bigger, older firms tend to invest more.

Finally, for an investment made in year $t$, we construct a measure of the total prior investments of the owner equal to the total number of affiliates the owner had listed in Amadeus that existed in year $t-1 .^{30}$ Table 3 presents the breakdown of the prior investment experience of owners. ${ }^{31}$ As can be seen, $75 \%$ of owners had no prior investment experience before they made the investment we modeled. Of those that did have prior experience, roughly half had invested only one other time. ${ }^{32}$ Our priors are that firms that have previous experience with overseas investment may be more likely to invest again (which as this does not vary by host cannot be estimated),

\footnotetext{
27 Note that in unreported results we examine the growth of the affiliates by using their size in year $t+1$, $t+2$, and $t+3$. This does not affect our results and suggests that, if as according to Hartman (1985) firms underinvest to grow via retained earnings, that growth takes some time to manifest itself.

28 This excludes 524 investments, the bulk of which report zero affiliate assets.

29 NACE dummies are automatically controlled for in the extensive margin estimates and are included in the intensive estimates. In the online appendix, we report results for three sectors: manufacturing, services, and financial services. The latter two sub-samples confirm the overall results whereas those for manufacturing are quite different. While this is reminiscent of the results of Lawless et al. (2018) given the small number of manufacturing investment projects, we hesitate to make too much of these results. In addition, using repeated subsamples of the services investments suggests that the number of observations in manufacturing may play a part in the differences. See the online appendix for further discussion.

30 Note that as there is a great deal of missing information on total assets, particularly for non-European affiliates, we use the number rather than the size of these prior affiliates.

31 This was calculated as the number of investments prior to the first investment in the sample.

32 One firm had 198 prior investments and another had 918. When we exclude firms in the top percentile of prior investment experience, that is those with more than 52 prior investments, this had little impact on our results.
} 
have more tax minimizing options (and thus have a higher $\alpha_{o}$ ), and may tend to invest more given that investment occurs. We must note that this variable is based on the owner's investments listed in Amadeus and therefore may be missing some investments because they were missed by the data collectors, went out of business prior to the 2007 start of the data, or were in countries not covered by Amadeus.

Similar to Table 3 which found that most firms had little prior investment experience, Table 4 shows that most of the 6,643 owners only had one new investment during our sample. Of the $15 \%$ of firms that did have multiple investments during the sample, they accounted for $30 \%$ of the investments we model. Further, those "multi-investors" accounted for $61 \%$ of the value of the new investments in our sample. This suggests that FDI patterns may follow those found in trade where a small number of "superstar" firms account for a disproportionately large share of exporting activity. ${ }^{33}$

In addition to the owner variables, we utilize a set of home, host, and country pair control variables commonly used in FDI regressions. In determining our set of control variables, we draw from the overall FDI literature summarized by Blonigen and Piger (2014). ${ }^{34}$ To control for the market size of the countries, we utilize GDP and market potential (constructed as the sum of other countries' GDPs weighted by their distance to the country in question). We generally expect a positive effect from home and host GDP at both the extensive and intensive margins (i.e., investment is more likely and bigger in large economies). Market potential is typically presumed to have positive effects on FDI and indeed, this is commonly found [see for example Head and Mayer (2004) or the review by Fontagné and Mayer (2005)]. That said, several studies such as Blonigen et al. (2007) instead find the opposite, implying that investment prefers the periphery. As shown by Blonigen et al. (2007), the extent of this can vary across industry. Thus, we are initially agnostic about the expected effect of market potential. In addition, we include GDP per capita which can capture both desirable market income effects (encouraging FDI to locate there), higher skill levels (the attractiveness of which may depend on the skill-intensity of the industry), and higher worker wages (driving investment away). ${ }^{35}$ Thus, it is unclear what to anticipate for this variable a priori.

Beyond market size, we control for the level of tertiary education of the home and host (measured as the share of population with tertiary education). Much like GDP per capita, this can have a positive effect (reflecting skill) or a negative effect (reflecting costs). Also, as is common, we control for "openness", i.e., exports and imports relative to GDP. This is one measure of an economy's trade barriers which is generally seen as a hindrance to both outbound and inbound horizontal FDI but something that increases vertical FDI. In addition to this, we include dummies for whether the

\footnotetext{
$\overline{33}$ See Freund and Pierola (2015) for discussion.

34 In particular, we look to the work on discrete location decisions such as Head et al. (1995), Crozet et al. (2004), Brülhart et al. (2012), Basile et al. (2008), Chen and Moore (2010), Siedschlag et al. (2013a, 2013b).

35 Note that, as GDP and GDP per capita are in logs, this is equivalent to including GDP and population in logs. Also, the correlation coefficient between GDP and GDP per capita is small, 0.234 for the home country and 0.236 for the host.
} 
home-host country pair are both EU15 members or Eurozone members. ${ }^{36}$ We also use three pair-wise proxies for the cost of doing business across borders: contiguity, common language, and distance (measured as the distance between the most important cities in terms of population). These were obtained from the CEPII. ${ }^{37}$ Beyond these, we include the average FDI investment barrier index developed by the OECD. This index combines data on four subcategories restricting foreign-owned firms (equity restrictions on foreign ownership, screen and approval requirements, the use of key foreign personnel, and other restrictions). As this is about the establishment of the firm rather than affecting its marginal costs, we use this only in our extensive margin selection stage, where we anticipate a negative coefficient. ${ }^{38}$

Finally, and for us our variable of focus, we use two (logged) measures of the corporate tax rate, the effective average tax rate (EATR) and the effective marginal tax rate (EMTR), which come from CBT Tax Database. ${ }^{39}$ As discussed by Devereux et al. (2010), this methodology begins with statutory rates which are then adjusted for a representative firm accounting for each country's particular tax policies. ${ }^{40}$ In particular, and crucial for our analysis, this is done both for the average and the marginal tax. When choosing whether or not to locate in a given host country, the firm would consider the total after tax profit. In this case, as discussed by Devereux and Griffith (1998), the relevant tax is the average tax. Alternatively, if the question is how taxes affect marginal, intensive decisions, the appropriate tax rate to use is the effective marginal tax rate. Unless the tax system is flat, these two will typically differ. In our sample, the correlation between the host EATR and EMTR is .704 whereas that between the home taxes is .6854 . Furthermore, due to the large tax benefits from debt financing at the margin (see Graham (2000), for a thorough discussion), the marginal rate is on average less than the average rate. Figure 1 illustrates for our hosts using the average over the years of our sample. While our preferred specification is to use the log of the EATR and EMTR, we experiment with other measures including the level of taxes as well as the statutory tax rates. ${ }^{41}$

\footnotetext{
36 The correlation between these two is 0.568 . When only one is included, results are broadly similar, as demonstrated in the online appendix.

37 See http://www.cepii.fr.

38 Note that this is not origin specific. Particularly in light of the EU, investment barriers may differ between EU members and country pairs involving a non-member. Potential issues are hopefully mitigated by the inclusion of dummies equal to one with both countries are EU15 or Eurozone. In any case, however, if this measure was a poor indicator of investment barriers one would expect insignificance rather than the consistently significantly negative coefficient we find.

39 This can be found at https://ora.ox.ac.uk/objects/uuid:81f28d9a-fe6e-445b-8d34-a641b573d986.

40 Although we refer the reader to Devereux and Griffith (2003) for a detailed discussion, intuitively, this approach constructs a hypothetical firm with a given holding of industrial buildings, intangible assets, and so forth. For each of these, the country-specific tax offsets are calculated, assuming a depreciation schedule, and deducted from the statutory corporate tax to arrive at the effective rates. In unreported results, as an alternative to these constructed tax rates, we used those constructed by Spengel et al. (2014), who use a comparable methodology for European countries. When doing so, similar results were found.

41 As pointed out by Hines (1996) among many others, increases in taxes tend to have a larger impact when taxes are initially low. This motivates our use of logs which controls for this.
} 
Note that, unlike Egger and Merlo (2011) and Behrendt and Wamser (2018) who use the difference between the home and host tax, we only use the host tax. These two are, however, equivalent. This is because if one includes the tax difference $\tau_{m, t}-\tau_{h, t}$ as an element of the controls that vary across hosts $\mathbf{Z}_{m, h, t}$, that the home tax can be separated out from $\mathbf{Z}_{m, h, t}$ and instead included in the vector $\mathbf{X}_{o, m, t}$ which does not vary by host. Thus, the only source of variation in the tax differential used by the logit estimators is that arising from the host tax and, as such, we simply specify our regression as such. ${ }^{42}$ As a final note on our tax measures, in an optimal tax setting it is natural to consider taxes to be endogenous and dependent on the elasticity of capital flows (which itself would depend on taxes elsewhere with tax competition). Here, however, we treat taxes as exogenous. We believe that this is reasonable because the tax measures are constructed from national, statutory tax rates, not those specific to an individual firm. Although the national tax policy may be influenced by overall FDI, we believe it is unlikely to be driven by a single potential investment project. This is reinforced by EU prohibition of discriminatory tax treatment of domestic and foreign firms. Further, within the European data we use, the ability to provide firmspecific incentive packages is limited by regulations prohibiting state aid which have been interpreted to include firm-specific tax concessions. Thus, in our context, we do not believe that endogeneity of the tax variable is a major concern. ${ }^{43}$

Table 5 presents our summary statistics. Note that all non-binary variables are logged, including the size of the affiliate and that explanatory variables are lagged by one year relative to the date of investment.

\section{Results}

In Table 6, we present our baseline estimates. Columns (1) and (2) show the estimates for the conditional logit extensive and intensive decisions; columns (3) and (4) do so when using the mixed logit. Comparing the extensive and intensive results, recall that in the logit class of estimators, only variables which vary by potential host can be included in the extensive margin estimations and therefore columns (1) and (3) do not report coefficients for, e.g., home GDP or owner size. Note that the tax rates in the extensive columns are EATRs; those in the intensive columns are EMTRs. On the whole, however, we find very similar estimated effects regardless of the estimator employed.

We begin our discussion with the tax rates. As can be seen, for both conditional and mixed logit, we find that a higher host EATR significantly reduces the probability of investment. This is consistent with the conditional logit findings of papers such as Barrios et al. (2012) and Lawless et al. (2018) and the mixed logit results of, e.g., Behrendt and Wamser (2018) and Davies et al. (2018). Although the coefficient in the mixed logit model is negative, recall that this is the average

\footnotetext{
42 Confirmatory results of the equivalence of these two approaches are available on request.

43 Note that by including the inverse Mills ratio in the intensive estimation, we are controlling for the impact taxes may have on selection and mitigate potential bias from that source.
} 


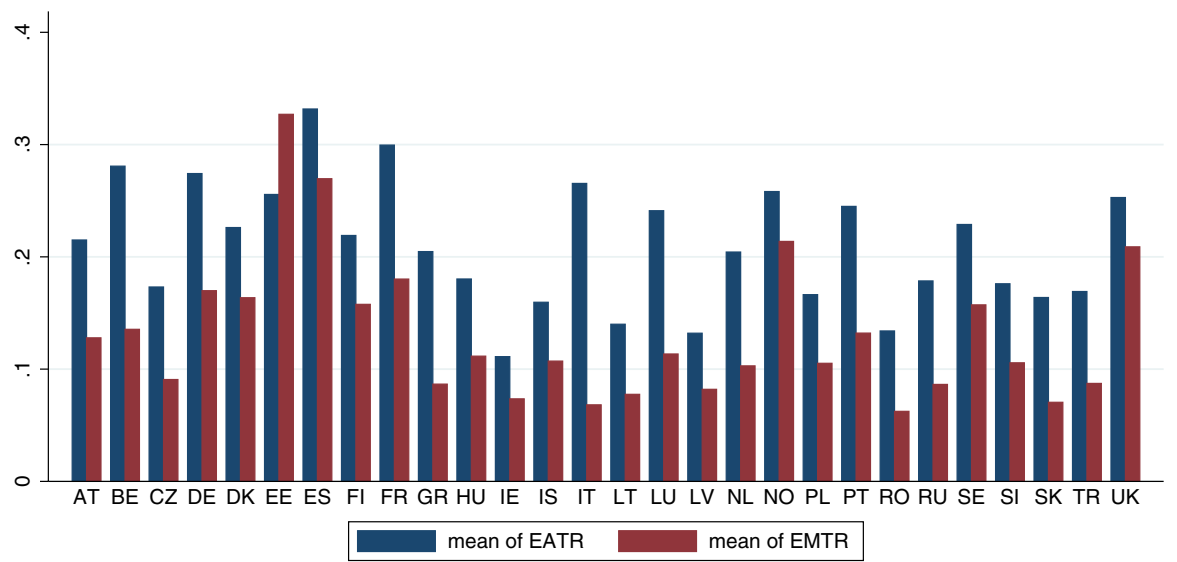

Fig. 1 EATR and EMTR. Source CBT Tax Database (2019). Note that values are means over the sample

Table 1 Home and host countries

\begin{tabular}{lrllrr}
\hline & Home & Host & Home & Host \\
\hline Austria & 339 & 381 & Italy & 504 & 574 \\
Australia & 9 &. & South Korea & 12 & $\cdot$ \\
Belgium & 1005 & 170 & Lithuania & 37 & 20 \\
Bulgaria & 15 &. & Luxembourg & 376 & 69 \\
Switzerland & 7 &. & Latvia & 35 & 154 \\
Cyprus & 7 &. & Montenegro & 41 & $\cdot$ \\
Czech Rep. & 314 & 371 & Netherlands & 1286 & 700 \\
Germany & 727 & 962 & Norway & 217 & 241 \\
Denmark & 100 & 176 & Poland & 58 & 428 \\
Estonia & 112 & 161 & Portugal & 166 & 227 \\
Spain & 546 & 353 & Romania & 11 & 855 \\
Finland & 227 & 105 & Russia & 5 & 81 \\
France & 357 & 440 & Sweden & 580 & 280 \\
Greece & 13 & 9 & Slovenia & 50 & 27 \\
Croatia & 30 &. & Slovakia & 190 & 456 \\
Hungary & 239 & 45 & Turkey & 34 & 1 \\
Ireland & 154 & 87 & Ukraine & 7 & $\cdot$ \\
Israel & 1 &. & United Kingdom & 356 & 834 \\
India & 14 &. & USA & 6 & $\cdot$ \\
Iceland & 27 & 12 & South Africa & 5 & $\cdot$ \\
& & & Total & 8219 & 8219 \\
\hline
\end{tabular}

Source Own calculations based on the Amadeus database (2019)

effect. The statistically significant standard deviation of the coefficient suggests that there is indeed heterogeneity in the way MNEs respond to host taxes. Overall, the estimates indicate that for $57 \%$ of firms the effect is negative, while for 
Table 2 Investments by Year

\begin{tabular}{lcc}
\hline Year & Number & Share $(\%)$ \\
\hline 2007 & 1098 & 13 \\
2008 & 1001 & 12 \\
2009 & 887 & 11 \\
2010 & 1054 & 13 \\
2011 & 1122 & 14 \\
2012 & 1152 & 14 \\
2013 & 1097 & 13 \\
2014 & 706 & 9 \\
2015 & 102 & 1 \\
Total & 8219 & 100 \\
\hline
\end{tabular}

Source Own calculations based on the Amadeus database (2019)

Table 3 Number of prior investments

\begin{tabular}{|c|c|c|}
\hline No. & No. of owners & $\begin{array}{l}\text { Share of } \\
\text { owners } \\
(\%)\end{array}$ \\
\hline 0 & 4992 & 75.15 \\
\hline 1 & 770 & 11.59 \\
\hline 2 & 312 & 4.70 \\
\hline 3 & 145 & 2.18 \\
\hline 4 & 81 & 1.22 \\
\hline 5 & 63 & 0.95 \\
\hline 6 & 40 & 0.60 \\
\hline 7 & 33 & 0.50 \\
\hline 8 & 37 & 0.56 \\
\hline 9 & 26 & 0.39 \\
\hline 10 & 15 & 0.23 \\
\hline 11 to 20 & 84 & 1.26 \\
\hline 21 to 50 & 39 & 0.59 \\
\hline 51 to 100 & 6 & 0.09 \\
\hline Total & 6643 & 100 \\
\hline
\end{tabular}

Source: Own calculations based on the Amadeus database (2019)

the remaining $43 \%$ it is positive. ${ }^{44}$ In terms of magnitude, the conditional logit estimates in column (1) result in an estimated elasticity of -0.348 for the host EATR. For mixed logit, we are forced to simulate the change generated by a one percent increase in the logged EATR, a process which yields an average change in the probability of investment of -0.631 . Note, however, that this methodology

\footnotetext{
$\overline{44}$ These numbers are given by $100 * \Phi\left(-\hat{\alpha}_{o} / \hat{s}_{o}\right)$, where $\phi$ is cumulative standard normal distribution and $\hat{\alpha}_{o}$ and $\hat{s}_{o}$ are the estimated mean and standard deviation of the coefficient for the host tax.
} 
Table 4 Number of investments during sample

\begin{tabular}{lrcc}
\hline $\begin{array}{l}\text { No. of invest- } \\
\text { ments }\end{array}$ & No. of owners & $\begin{array}{l}\text { Share of invest- } \\
\text { ments }(\%)\end{array}$ & $\begin{array}{l}\text { Share of } \\
\text { owners } \\
(\%)\end{array}$ \\
\hline 1 & 5693 & 69.27 & 85.70 \\
2 & 646 & 15.72 & 9.72 \\
3 & 168 & 6.13 & 2.53 \\
4 & 75 & 3.65 & 1.13 \\
5 & 20 & 1.22 & 0.30 \\
6 & 22 & 1.61 & 0.33 \\
7 & 5 & 0.43 & 0.08 \\
8 & 4 & 0.39 & 0.06 \\
9 & 2 & 0.22 & 0.03 \\
10 & 1 & 0.12 & 0.02 \\
11 & 1 & 0.13 & 0.02 \\
13 & 1 & 0.16 & 0.02 \\
14 & 1 & 0.17 & 0.02 \\
15 & 1 & 0.18 & 0.02 \\
16 & 1 & 0.19 & 0.02 \\
17 & 2 & 0.41 & 0.03 \\
8219 & 6643 & 100 & 100 \\
\hline
\end{tabular}

Source: Own calculations based on the Amadeus database (2019)

does not result in standard errors for this change. That said, it does fall in the 95\% confidence interval for the conditional logit estimate. Moving to the intensive margin (columns 2 and 4), neither home nor host effective marginal tax rates appear to impact the size of investment regardless of the estimation methodology.

Switching to the country-pair variables, we find that while all are significant for the extensive margin that the coefficients are often insignificant for the intensive margin. Given this, and that home variables can only be included in the intensive margin estimation, in our discussion we focus just on those that vary by host. Distance, which is typically found to reduce FDI, does so at the extensive margin; however, given that investment occurs, affiliate size is not significantly affected by the distance. Contiguity and common language exhibit a comparable pattern (although the latter also affects the intensive margin when using mixed logit).

Country openness is similarly significant only in the extensive margin. There, it is significantly negative, suggestive of horizontal style FDI (Markusen 1984). Host tertiary education is also negatively significant in the extensive margin, which would be consistent with highly educated workers being costly (or affiliate activity being relatively low-skill intensive).

Looking to our three market size variables, host GDP is positively correlated with the probability of an investment. That said, although investment is more likely in a larger host, affiliate size is significantly smaller. These patterns are reversed for GDP per capita, where the estimates indicate that FDI tends to avoid high-income hosts, 
Table 5 Summary statistics

\begin{tabular}{|c|c|c|c|c|c|}
\hline & Obs. & Mean & SD & Min & $\operatorname{Max}$ \\
\hline \multicolumn{6}{|l|}{ Firm-level } \\
\hline Affiliate size & 8219 & -6.11 & 2.41 & -11.69 & 3.49 \\
\hline Owner size & 230,132 & -3.46 & 2.63 & -11.68 & 7.07 \\
\hline Owner age & 230,132 & 1.91 & 1.13 & 0.00 & 5.12 \\
\hline Total prior investment & 230,132 & 0.39 & 0.86 & 0.00 & 4.45 \\
\hline \multicolumn{6}{|l|}{ Country-level } \\
\hline EATR home & 230,132 & -1.45 & 0.23 & -2.51 & -1.04 \\
\hline EATR host & 230,132 & -1.59 & 0.28 & -2.20 & -1.04 \\
\hline EMTR home & 230,132 & -2.05 & 0.77 & -9.21 & -1.05 \\
\hline EMTR host & 230,132 & -2.19 & 0.81 & -9.21 & -1.05 \\
\hline GDP home & 230,132 & 13.10 & 1.31 & 8.72 & 16.44 \\
\hline GDP host & 230,132 & 12.37 & 1.50 & 9.51 & 14.98 \\
\hline GDP/Capita home & 230,132 & -3.39 & 0.52 & -7.15 & -2.45 \\
\hline GDP/Capita host & 230,132 & -3.76 & 0.76 & -5.28 & -2.45 \\
\hline Mkt. Potential home & 230,132 & 10.23 & 0.41 & 8.26 & 10.82 \\
\hline Mkt. Potential host & 230,132 & 9.99 & 0.35 & 9.41 & 10.82 \\
\hline Openness home & 230,132 & 4.65 & 0.48 & 3.34 & 6.08 \\
\hline Openness host & 230,132 & 4.57 & 0.47 & 3.82 & 6.08 \\
\hline Tertiary home & 230,132 & 3.35 & 0.29 & 1.65 & 4.02 \\
\hline Tertiary host & 230,132 & 3.30 & 0.34 & 2.56 & 4.06 \\
\hline FDI barriers & 230,132 & 4.45 & 0.09 & 4.09 & 4.55 \\
\hline \multicolumn{6}{|l|}{ Pair-level } \\
\hline Both EU15 & 230,132 & 0.44 & 0.50 & 0 & 1 \\
\hline Both Euro & 230,132 & 0.37 & 0.48 & 0 & 1 \\
\hline Distance & 230,132 & 6.94 & 0.81 & 2.95 & 9.81 \\
\hline Contiguity & 230,132 & 0.12 & 0.32 & 0 & 1 \\
\hline Common Language & 230,132 & 0.06 & 0.23 & 0 & 1 \\
\hline
\end{tabular}

Source: Own calculations based on the Amadeus database (2019)

given that investment occurs it tends to be larger. Similarly, a higher host market potential increases the probability of investment; however, conditional on investment, hosts located near other large markets tend to have smaller affiliates. ${ }^{45}$ Thus, although investment is less likely in peripheral hosts, if it occurs, investment tends to be larger. When both the home and host are EU15 members, FDI is more likely. Somewhat surprisingly, the opposite is true when both are Euro members. ${ }^{46}$ Both of these impacts, however, are found at the extensive rather than intensive stage.

Turning to the owner characteristics, which like the home variables can only be included in the intensive margin estimation, we find significantly positive effects of

\footnotetext{
45 This is reminiscent of the negative impacts on aggregate FDI found by Blonigen et al. (2007).

46 While one might be concerned that this arises from collinearity between these, when omitting them individually we found signs matching those here.
} 
Table 6 Baseline results

\begin{tabular}{|c|c|c|c|c|}
\hline & \multicolumn{2}{|c|}{ Conditional logit } & \multicolumn{2}{|l|}{ Mixed logit } \\
\hline & (1) & (2) & (3) & (4) \\
\hline & Extensive & Intensive & Extensive & Intensive \\
\hline \multirow[t]{2}{*}{ Host tax (EATR/EMTR) } & $-0.843 * * *$ & 0.007 & $-0.480 * * *$ & -0.006 \\
\hline & $(0.103)$ & $(\mathbf{0 . 0 3 0})$ & $(0.107)$ & $(0.029)$ \\
\hline \multirow[t]{2}{*}{ SD EATR host } & & & $2.645^{* * *}$ & \\
\hline & & & $(0.107)$ & \\
\hline \multirow[t]{2}{*}{ Home tax (EMTR) } & & -0.027 & & -0.027 \\
\hline & & $(0.039)$ & & $(0.039)$ \\
\hline \multirow[t]{2}{*}{ Owner size } & & $0.262 * * *$ & & $0.262 * * *$ \\
\hline & & $(0.016)$ & & $(0.016)$ \\
\hline \multirow[t]{2}{*}{ Owner Age } & & $-0.240 * * *$ & & $-0.239 * * *$ \\
\hline & & $(0.028)$ & & $(0.028)$ \\
\hline \multirow[t]{2}{*}{ Total prior investment } & & $0.119 * *$ & & $0.119 * *$ \\
\hline & & $(0.049)$ & & $(0.049)$ \\
\hline \multirow[t]{2}{*}{ Distance } & $-0.424 * * *$ & 0.323 & $-0.491 * * *$ & 0.107 \\
\hline & $(0.020)$ & $(0.197)$ & $(0.020)$ & $(0.121)$ \\
\hline \multirow[t]{2}{*}{ Contiguity } & $1.475 * * *$ & -1.069 & $1.474 * * *$ & -0.307 \\
\hline & $(0.035)$ & $(0.671)$ & $(0.035)$ & $(0.369)$ \\
\hline \multirow[t]{2}{*}{ Common Language } & $0.266^{* * *}$ & 0.149 & $0.290 * * *$ & $0.281 * *$ \\
\hline & $(0.049)$ & $(0.158)$ & $(0.051)$ & $(0.135)$ \\
\hline \multirow[t]{2}{*}{ Home openness } & & 0.855 & & 0.914 \\
\hline & & $(0.714)$ & & $(0.715)$ \\
\hline \multirow[t]{2}{*}{ Host openness } & $-1.182 * * *$ & -0.456 & $-1.232 * * *$ & -1.145 \\
\hline & $(0.076)$ & $(0.947)$ & $(0.076)$ & $(0.802)$ \\
\hline \multirow[t]{2}{*}{ Home tertiary } & & -0.350 & & -0.365 \\
\hline & & $(0.711)$ & & $(0.713)$ \\
\hline \multirow[t]{2}{*}{ Host tertiary } & $-1.266 * * *$ & 0.957 & $-1.421 * * *$ & 0.257 \\
\hline & $(0.046)$ & $(0.948)$ & $(0.052)$ & $(0.833)$ \\
\hline \multirow[t]{2}{*}{ Home GDP } & & -3.368 & & -3.268 \\
\hline & & $(2.394)$ & & $(2.390)$ \\
\hline \multirow[t]{2}{*}{ Host GDP } & $0.111 * * *$ & $-6.125 * *$ & $0.079 * * *$ & $-6.495 * *$ \\
\hline & $(0.020)$ & $(2.577)$ & $(0.020)$ & $(2.572)$ \\
\hline \multirow[t]{2}{*}{ Home GDP/Capita } & & 2.792 & & 2.973 \\
\hline & & $(2.219)$ & & $(2.221)$ \\
\hline \multirow[t]{2}{*}{ Host GDP/Capita } & $-0.162 * * *$ & $5.272 * *$ & $-0.118 * * *$ & $5.346 * *$ \\
\hline & $(0.035)$ & $(2.161)$ & $(0.036)$ & $(2.162)$ \\
\hline \multirow[t]{2}{*}{ Home Mkt. Potential } & & -3.010 & & -3.035 \\
\hline & & $(5.116)$ & & $(5.120)$ \\
\hline \multirow[t]{2}{*}{ Host Mkt. Potential } & $1.240 * * *$ & $-24.340 * * *$ & $1.288^{* * * *}$ & $-24.134 * * *$ \\
\hline & $(0.084)$ & $(6.535)$ & $(0.085)$ & $(6.536)$ \\
\hline \multirow[t]{2}{*}{ Both EU15 } & $0.579 * * *$ & -0.353 & $0.622 * * *$ & -0.027 \\
\hline & $(0.056)$ & $(0.307)$ & $(0.062)$ & $(0.200)$ \\
\hline
\end{tabular}


Table 6 (continued)

\begin{tabular}{|c|c|c|c|c|}
\hline & \multicolumn{2}{|c|}{ Conditional logit } & \multicolumn{2}{|l|}{ Mixed logit } \\
\hline & (1) & (2) & (3) & (4) \\
\hline Both Euro & $\begin{array}{l}-0.752^{* * * *} \\
(0.043)\end{array}$ & $\begin{array}{l}0.463 \\
(0.357)\end{array}$ & $\begin{array}{l}-0.859 * * * \\
(0.046)\end{array}$ & $\begin{array}{l}0.101 \\
(0.260)\end{array}$ \\
\hline Host FDI barriers & $\begin{array}{l}-0.651 * * * \\
(0.152)\end{array}$ & & $\begin{array}{l}-1.154 * * * \\
(0.160)\end{array}$ & \\
\hline Inverse Mills ratio & & $\begin{array}{l}-0.023 \\
(0.016)\end{array}$ & & $\begin{array}{l}-0.005 \\
(0.009)\end{array}$ \\
\hline Constant & & $\begin{array}{l}361.604 * * * \\
(99.449)\end{array}$ & & $\begin{array}{l}394.217 * * * \\
(105.902)\end{array}$ \\
\hline Observations & 230,132 & 8219 & 230,132 & 8219 \\
\hline$R$-squared & & 0.273 & & 0.273 \\
\hline Log likelihood & $-22,683$ & $-17,576$ & $-22,74$ & $-17,577$ \\
\hline
\end{tabular}

Standard errors are clustered at the owner-level. *** $p<0.01, * * p<0.05, * p<0.1$. Intensive margin estimates include home, host, owner sector, affiliate sector, and year dummies. All continuous variables are in logs

owner size, where this means that larger owners tend to have larger affiliates (even after controlling for owner and affiliate industry). This would be consistent with more productive owners having larger affiliates. Owner age, however, is negatively significant in the intensive stage, meaning that older owners tend to establish smaller affiliates. Finally the total number of prior investments is positive and significant which suggests that prior FDI experience is positively correlated with larger subsequent investments.

The final variables in Table 6 relate to selection. In addition to the EATRs, the extensive stage includes the FDI barrier measure which, as expected is significantly negative. The inverse mills ratio is, however, insignificant in both columns (2) and (4), suggesting that there is little impact of sample selection when estimating investment size.

\subsection{Heterogeneous tax sensitivity}

As we have mentioned in the previous section, even though the coefficient on host EATR in the mixed logit model is -0.48 , the estimated standard deviation of the coefficient suggests that there is significant heterogeneity in the way multinationals respond to taxes, with the estimated effect ranging from -6.42 to 4.99 . In this section, we look at how this heterogeneity is related to observable characteristics of the owner and its home country. To do so, following Equation 5, we regress the estimated firm-specific $\alpha_{o}$ on various firm and home country variables. ${ }^{47}$

\footnotetext{
47 Note that we do this because, recalling that the logit estimators rely on variation across options, interacting a variable that does not vary across hosts (e.g., owner size) with one that does (e.g., the host EATR) would result in a coefficient primarily driven by variation in the EATR itself which is already being controlled for.
} 
Table 7 presents the results from this exercise. We begin by consecutively adding three owner characteristics: size, age, and prior investments. Across columns (1) to (3), owner size is positive and significant, indicating that consistent with our prior belief that large companies are less sensitive to taxes. The coefficient on owner age is negative, suggesting that older owners tend to be more deterred by higher taxes in the host countries. If younger firms' intangible assets have fewer arms-length comparables due to their more recent development, this may make it easier for these firms to transfer price and avoid host taxation. ${ }^{48}$ As such, older firms may be more responsive to host taxes. We do not, however, find a significant effect of the total prior investment.

In columns (4)-(6), we introduce home country variables. Of these, two are significant: home GDP and the home EATR. For both, we find a negative coefficient, i.e., firms from large, high tax countries are more sensitive to the host tax rate. These may be because such firms have significant home taxes that they seek to offshore to low tax jurisdictions.

Given these results in Table 8 we use the significant variables in Table 7 to construct interactions with the host tax to see whether this reveals heterogeneity at the intensive margin, i.e., although the average effect of the host tax may be zero, there may be underlying significant effects that vary across firms. In column (1), we again show the extensive estimates from the baseline mixed logit results. In column (2), for comparison, we also show the baseline intensive results from the mixed logit. Column (3) introduces the interactions of the host tax with owner size and age. Column (4) extends the model to include interactions between the host EMTR and the home country's GDP and EATR. When doing so, we continue to find little significant impact of taxes on the intensive margin. The exception to this is the interaction between owner size and the host EMTR which is positive and marginally significant. This reinforces the suggestion in Table 7 that any potential negative effect of the host tax is more important for small MNEs than large ones. ${ }^{49}$

\subsection{Alternative tax measures}

In the above estimation, we use the log of the home and host taxes, using the EATR in the extensive margin and the EMTR in the intensive margin in accordance with the theory. However, one might be concerned that the use of logs or the way in which the effective taxes are constructed may be driving the result that taxes deter FDI but only at the extensive margin. In addition, the literature shows that the statutory tax rate has often stronger predictive power (see e.g., Buettner and Ruf 2007).

With this in mind, Table 9 uses the levels rather than the logs of the EATR and EMTR. As can be seen, this does not alter the overarching conclusions. We continue to find an average negative effect of the host tax on the location choice with

\footnotetext{
48 This would be reminiscent of Davies et al. (2018) who find that transfer pricing in tangibles is primarily in differentiated products where arms-length comparables are difficult to identify.

49 Note that although the coefficient in column (3) is positive, it is well outside the normal range of significance.
} 
Table 7 Tax sensitivity

\begin{tabular}{|c|c|c|c|c|c|c|}
\hline & (1) & (2) & (3) & (4) & (5) & (6) \\
\hline Home tax (EATR) & & & & & $\begin{array}{l}-1.127 * * * \\
(0.313)\end{array}$ & $\begin{array}{l}-1.141 \text { *** } \\
(0.319)\end{array}$ \\
\hline Owner size & $\begin{array}{l}0.031 * * * \\
(0.008)\end{array}$ & $\begin{array}{l}0.038 * * * \\
(0.009)\end{array}$ & $\begin{array}{l}0.038^{* * *} \\
(0.009)\end{array}$ & $\begin{array}{l}0.038^{* * * *} \\
(0.009)\end{array}$ & $\begin{array}{l}0.038^{* * * *} \\
(0.009)\end{array}$ & $\begin{array}{l}0.039 * * * \\
(0.009)\end{array}$ \\
\hline Owner age & & $\begin{array}{l}-0.040^{* *} \\
(0.018)\end{array}$ & $\begin{array}{l}-0.040^{* *} \\
(0.018)\end{array}$ & $\begin{array}{l}-0.040^{* *} \\
(0.018)\end{array}$ & $\begin{array}{l}-0.041^{* *} \\
(0.018)\end{array}$ & $\begin{array}{l}-0.041^{* *} \\
(0.018)\end{array}$ \\
\hline Total prior investment & & & $\begin{array}{l}-0.004 \\
(0.039)\end{array}$ & $\begin{array}{l}-0.034 \\
(0.059)\end{array}$ & $\begin{array}{l}-0.035 \\
(0.059)\end{array}$ & $\begin{array}{l}-0.007 \\
(0.039)\end{array}$ \\
\hline Home GDP & & & & $\begin{array}{l}-3.649^{* *} \\
(1.527)\end{array}$ & $\begin{array}{l}-3.667 * * \\
(1.525)\end{array}$ & $\begin{array}{l}-3.699^{* *} \\
(1.534)\end{array}$ \\
\hline Home GDP/Capita & & & & $\begin{array}{l}1.562 \\
(1.481)\end{array}$ & $\begin{array}{l}1.746 \\
(1.483)\end{array}$ & $\begin{array}{l}1.482 \\
(1.517)\end{array}$ \\
\hline Home Mkt. potential & & & & & & $\begin{array}{l}2.190 \\
(2.501)\end{array}$ \\
\hline Home EU15 & & & & & & $\begin{array}{l}-7.814 \\
(4.871)\end{array}$ \\
\hline Home Euro & & & & & & $\begin{array}{l}0.199 \\
(0.214)\end{array}$ \\
\hline Constant & $\begin{array}{l}-1.011^{* * * *} \\
(0.245)\end{array}$ & $\begin{array}{l}-0.896^{* * *} \\
(0.251)\end{array}$ & $\begin{array}{l}-0.895^{* * *} \\
(0.252)\end{array}$ & $\begin{array}{l}50.498 * * \\
(23.717)\end{array}$ & $\begin{array}{l}49.672 * * \\
(23.688)\end{array}$ & $\begin{array}{l}34.783 \\
(32.579)\end{array}$ \\
\hline Observations & 6643 & 6643 & 6643 & 6643 & 6643 & 6643 \\
\hline$R$-squared & 0.105 & 0.106 & 0.106 & 0.108 & 0.109 & 0.110 \\
\hline
\end{tabular}

Standard errors are clustered at the owner-level. *** $p<0.01, * * p<0.05, * p<0.1$. All estimates include home, owner sector and year dummies. All continuous variables are in logs

significant heterogeneity around this mean (63\% of firms are estimated to have a negative coefficient). This approach does, however, suggest that the firm-specific $\alpha_{o}$ is more negative when the home is an EU15 country. The other difference is that this specification points to a larger and more significant coefficient on the interaction between the host EMTR and owner size in the intensive estimation.

Table 10 again uses logs but rather than effective taxes uses statutory tax rates (which are the same in both stages of the estimation). Again, the results find that taxes reduce FDI at the extensive but not the intensive margin, with $75 \%$ of owners being deterred by host taxes when choosing where to invest. The only major differences relate to the patterns in $\alpha_{o}$. Unlike the above results, the firm's host tax sensitivity is no longer correlated with home GDP. Further, in the intensive stage, the interaction between the host statutory tax and owner age is now insignificant while that with owner age is now marginally significant and negative. This points toward our results being driven by differences in the tax effects at the extensive rather than intensive margin rather than the role of the EATR relative to EMTR.

Thus, our primary finding is robust to alternative measures of the tax rates. 
Table 8 Interactions in the intensive estimation

\begin{tabular}{|c|c|c|c|c|}
\hline & (1) & $(2)$ & (3) & (4) \\
\hline & Extensive & Intensive & Intensive & Intensive \\
\hline \multirow[t]{2}{*}{ Host tax (EATR/EMTR) } & $-0.480 * * *$ & -0.006 & 0.093 & -0.119 \\
\hline & $(0.107)$ & (0.029) & $(0.075)$ & $(0.294)$ \\
\hline \multirow[t]{2}{*}{ SD EATR host } & $2.645 * * *$ & & & \\
\hline & $(0.107)$ & & & \\
\hline \multirow[t]{2}{*}{ Home tax (EMTR) } & & -0.027 & -0.027 & -0.027 \\
\hline & & $(0.039)$ & $(0.039)$ & $(0.040)$ \\
\hline \multirow[t]{2}{*}{ Owner size } & & $0.262 * * *$ & $0.305 * * *$ & $0.304 * * *$ \\
\hline & & $(0.016)$ & $(0.027)$ & $(0.028)$ \\
\hline \multirow[t]{2}{*}{ Owner age } & & $-0.239 * * *$ & $-0.273 * * *$ & $-0.271 * * *$ \\
\hline & & $(0.028)$ & $(0.053)$ & $(0.053)$ \\
\hline \multirow[t]{2}{*}{ Total prior investment } & & $0.119 * *$ & $0.118 * *$ & $0.118 * *$ \\
\hline & & $(0.049)$ & $(0.048)$ & $(0.048)$ \\
\hline \multirow[t]{2}{*}{ Distance } & $-0.491 * * *$ & 0.107 & 0.106 & 0.103 \\
\hline & $(0.020)$ & $(0.121)$ & $(0.121)$ & $(0.122)$ \\
\hline \multirow[t]{2}{*}{ Contiguity } & $1.474 * * *$ & -0.307 & -0.311 & -0.297 \\
\hline & $(0.035)$ & $(0.369)$ & $(0.368)$ & $(0.370)$ \\
\hline \multirow[t]{2}{*}{ Common Language } & $0.290 * * *$ & $0.281 * *$ & $0.272 * *$ & $0.281 * *$ \\
\hline & $(0.051)$ & $(0.135)$ & $(0.135)$ & $(0.135)$ \\
\hline \multirow[t]{2}{*}{ Home openness } & & 0.914 & 0.933 & 0.894 \\
\hline & & $(0.715)$ & $(0.716)$ & $(0.716)$ \\
\hline \multirow[t]{2}{*}{ Host openness } & $-1.232 * * *$ & -1.145 & -1.150 & -1.161 \\
\hline & $(0.076)$ & $(0.802)$ & $(0.802)$ & $(0.803)$ \\
\hline \multirow[t]{2}{*}{ Home tertiary } & & -0.365 & -0.366 & -0.386 \\
\hline & & $(0.713)$ & $(0.712)$ & $(0.713)$ \\
\hline \multirow[t]{2}{*}{ Host tertiary } & $-1.421 * * *$ & 0.257 & 0.249 & 0.235 \\
\hline & $(0.052)$ & $(0.833)$ & $(0.833)$ & $(0.833)$ \\
\hline \multirow[t]{2}{*}{ Home GDP } & & -3.268 & -3.248 & -3.326 \\
\hline & & $(2.390)$ & $(2.391)$ & $(2.385)$ \\
\hline \multirow[t]{2}{*}{ Host GDP } & $0.079 * * *$ & $-6.495^{* *}$ & $-6.432 * *$ & $-6.370^{* *}$ \\
\hline & $(0.020)$ & $(2.572)$ & $(2.567)$ & $(2.566)$ \\
\hline \multirow[t]{2}{*}{ Home GDP/Capita } & & 2.973 & 3.003 & 3.162 \\
\hline & & $(2.221)$ & $(2.229)$ & $(2.218)$ \\
\hline \multirow[t]{2}{*}{ Host GDP/Capita } & $-0.118 * * *$ & $5.346^{* *}$ & $5.262 * *$ & $5.240 * *$ \\
\hline & $(0.036)$ & $(2.162)$ & $(2.157)$ & $(2.158)$ \\
\hline \multirow[t]{2}{*}{ Home Mkt. Potential } & & -3.035 & -2.933 & -3.057 \\
\hline & & $(5.120)$ & $(5.113)$ & $(5.118)$ \\
\hline \multirow[t]{2}{*}{ Host Mkt. Potential } & $1.288 * * *$ & $-24.134 * * *$ & $-24.072 * * *$ & $-24.082 * * *$ \\
\hline & $(0.085)$ & $(6.536)$ & $(6.538)$ & $(6.535)$ \\
\hline \multirow[t]{2}{*}{ Both EU15 } & $0.622 * * *$ & -0.027 & -0.023 & -0.028 \\
\hline & $(0.062)$ & $(0.200)$ & $(0.200)$ & $(0.201)$ \\
\hline Both Euro & $-0.859 * * *$ & 0.101 & 0.108 & 0.097 \\
\hline
\end{tabular}


Table 8 (continued)

\begin{tabular}{|c|c|c|c|c|}
\hline & (1) & (2) & (3) & (4) \\
\hline & Extensive & Intensive & Intensive & Intensive \\
\hline & $(0.046)$ & $(0.260)$ & $(0.260)$ & $(0.261)$ \\
\hline Host FDI barriers & $\begin{array}{l}-1.154 * * * \\
(0.160)\end{array}$ & & & \\
\hline Inverse Mills ratio & & $\begin{array}{l}-0.005 \\
(0.009)\end{array}$ & $\begin{array}{l}-0.005 \\
(0.009)\end{array}$ & $\begin{array}{l}-0.005 \\
(0.009)\end{array}$ \\
\hline \multicolumn{5}{|l|}{ Interactions } \\
\hline Host EMTR $*$ Owner size & & & $\begin{array}{l}0.019 * \\
(0.010)\end{array}$ & $\begin{array}{l}0.019 * \\
(0.010)\end{array}$ \\
\hline Host EMTR * Owner age & & & $\begin{array}{l}-0.016 \\
(0.020)\end{array}$ & $\begin{array}{l}-0.015 \\
(0.019)\end{array}$ \\
\hline Host EMTR* Home EATR & & & & $\begin{array}{l}-0.012 \\
(0.085)\end{array}$ \\
\hline Host EMTR * Home GDP & & & & $\begin{array}{l}0.014 \\
(0.016)\end{array}$ \\
\hline Constant & & $\begin{array}{l}394.217 * * * \\
(105.902)\end{array}$ & $\begin{array}{l}391.944 * * * \\
(105.741)\end{array}$ & $\begin{array}{l}394.998 * * * \\
(106.003)\end{array}$ \\
\hline Observations & 230,132 & 8219 & 8219 & 8219 \\
\hline$R$-squared & & 0.273 & 0.274 & 0.274 \\
\hline log likelihood & $-22,474$ & $-17,577$ & $-17,574$ & $-17,574$ \\
\hline
\end{tabular}

Standard errors are clustered at the owner-level. $* * * p<0.01, * * p<0.05, * p<0.1$. Intensive margin estimates include home, host, owner sector, affiliate sector, and year dummies. All continuous variables are in logs

\section{Conclusion}

It has long been recognized that taxes affect both the size of aggregate investment and that this is the sum of firms' two-stage decisions: where to locate (the extensive margin) and how much to invest conditional on investment (the intensive margin). While a body of work points to significant effects of host taxes on the firm's decision of where to invest, the impact on the intensive margin is far less explored, particularly as part of this two-stage decision-making process. What evidence exists is mixed, potentially because the analysis is restricted to a single home country's firms and/or that it assumes that all multinationals respond equally to host taxes.

We relax both of these by employing a mixed logit estimator to examine over 8000 investments across 28 European countries from 40 home countries during 2007-2015. While we consistently find that host taxes affect the decision of whether or not to invest, conditional on investment, we find no evidence for an impact on the size of investment. In addition, while we consistently find that the average effect of host taxes on the extensive margin is negative, the data points to considerable heterogeneity in the size of this effect. This heterogeneity, however, does not appear to extend to the intensive margin. These findings are consistent with initial investments 


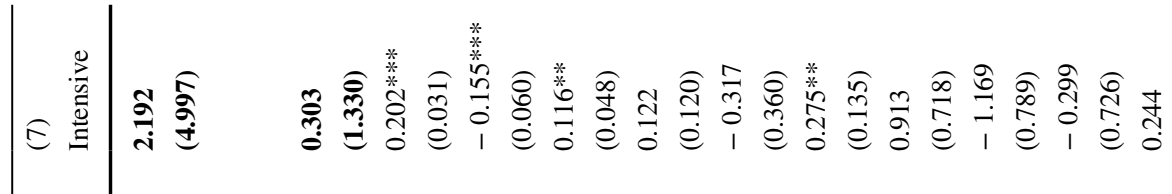

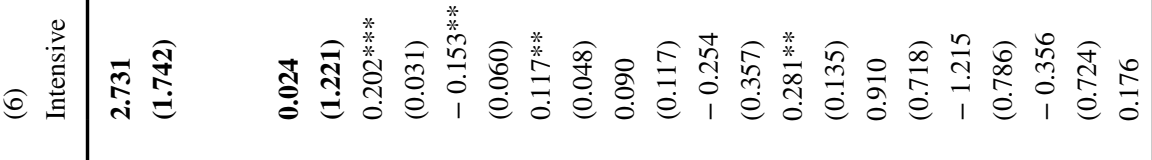

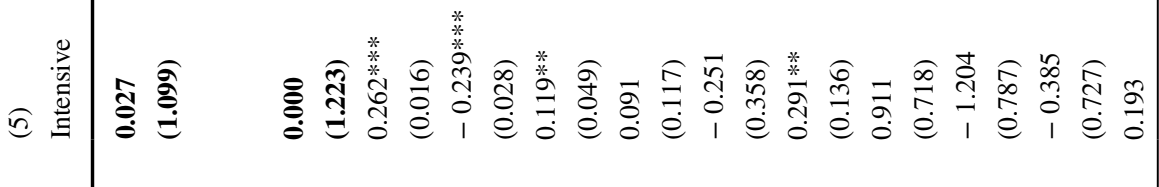

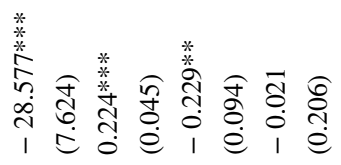

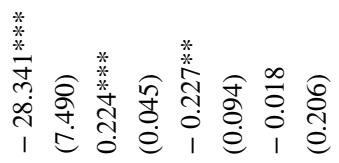

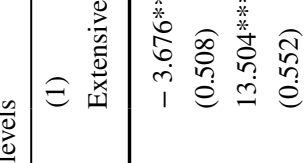

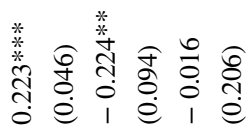

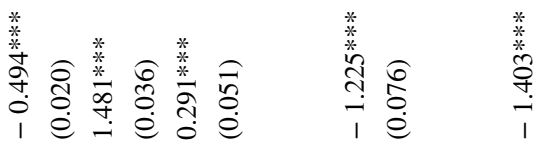

.$\Xi$

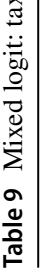

网

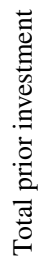

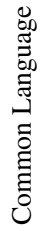

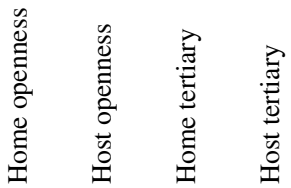




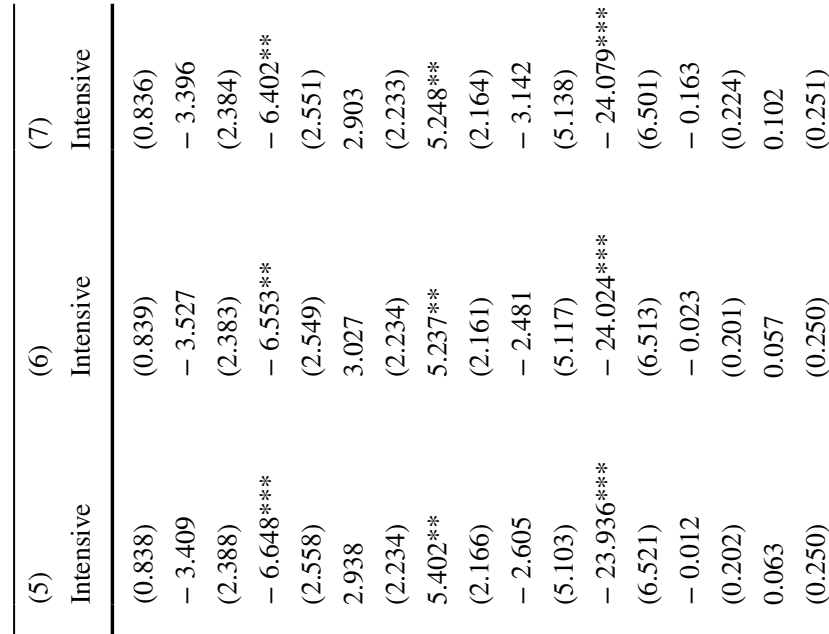

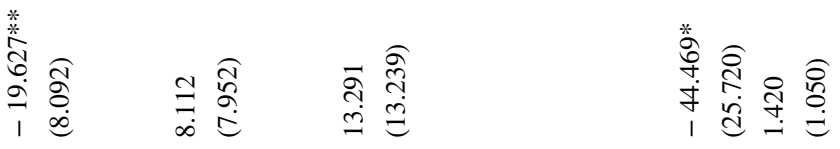

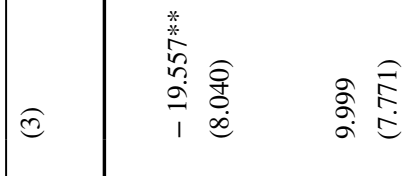

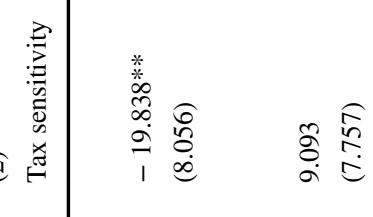

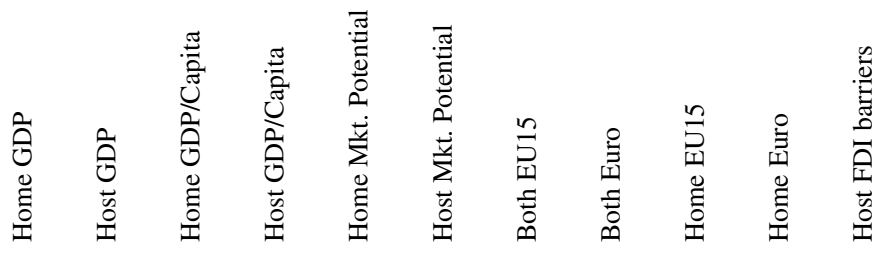




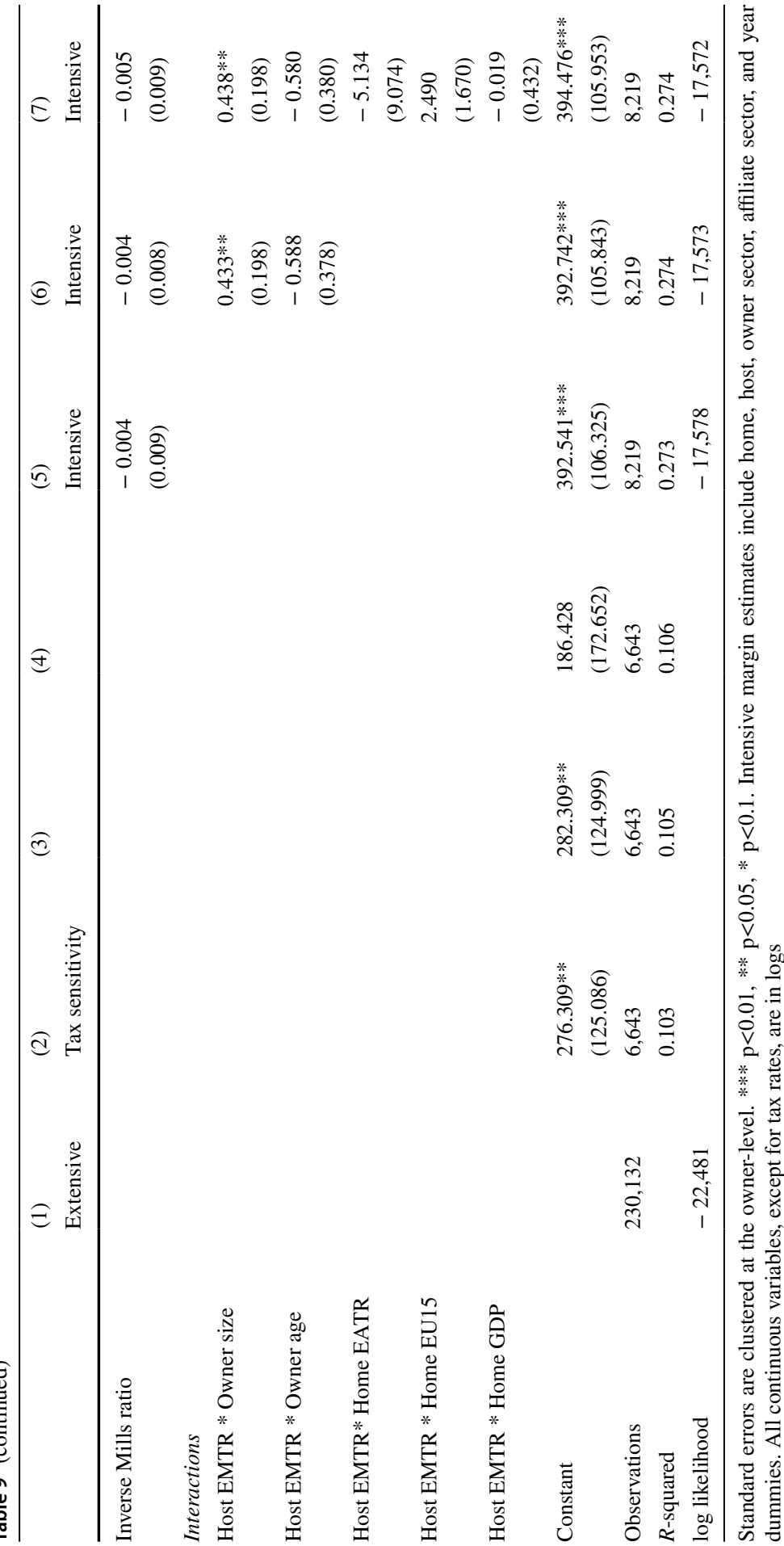




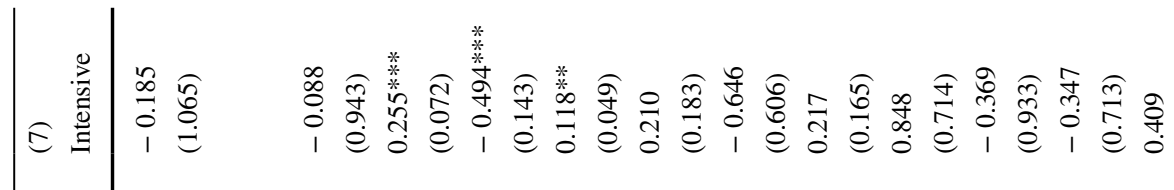

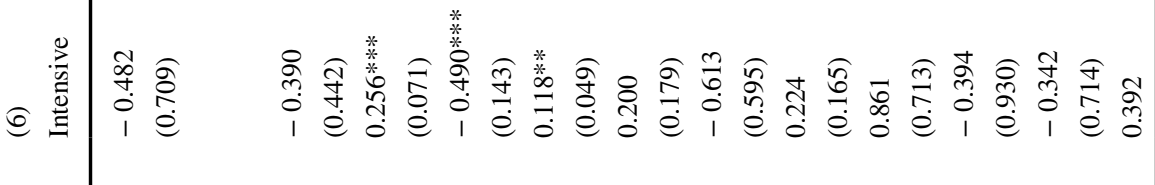

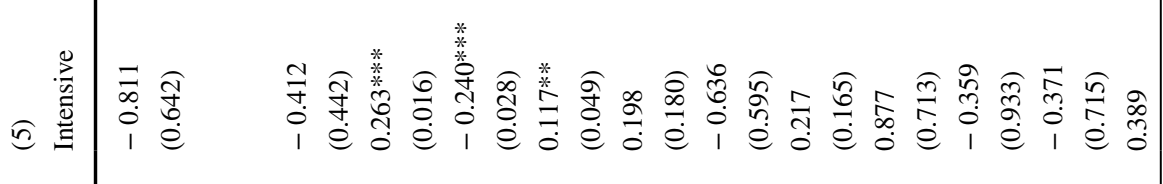

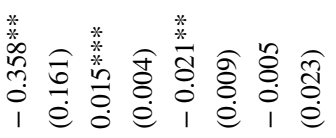

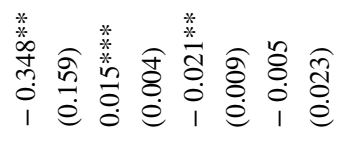

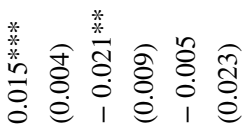




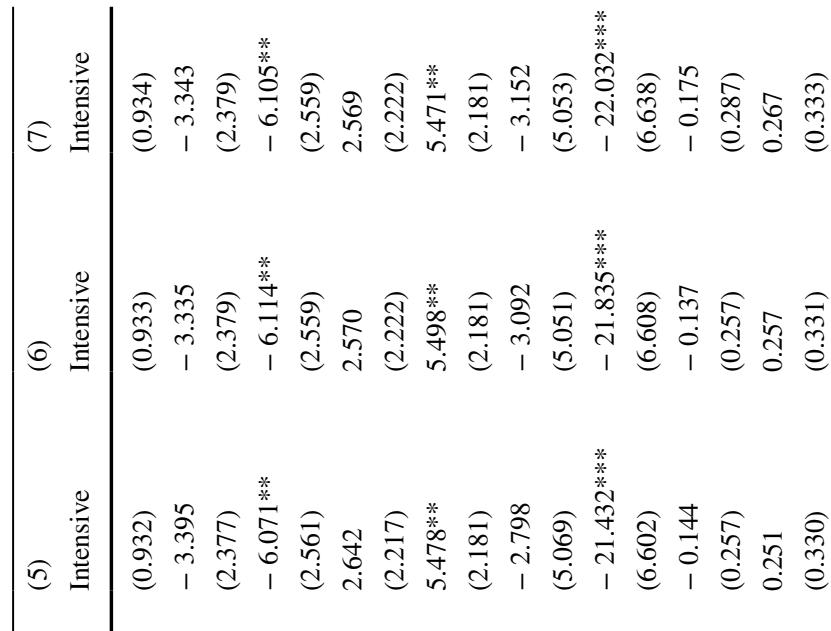

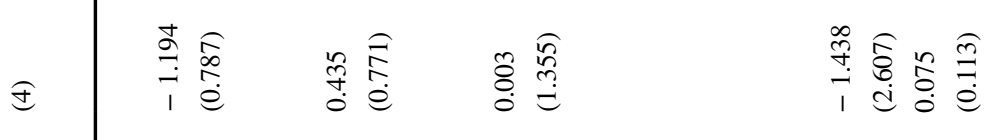

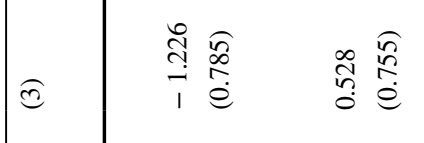

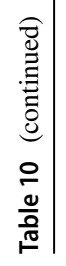

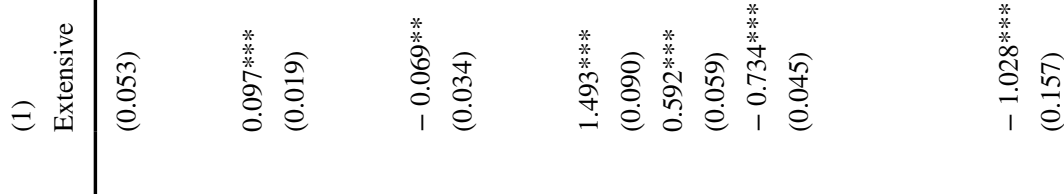

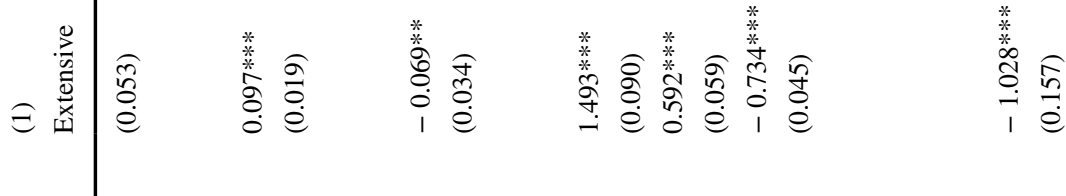

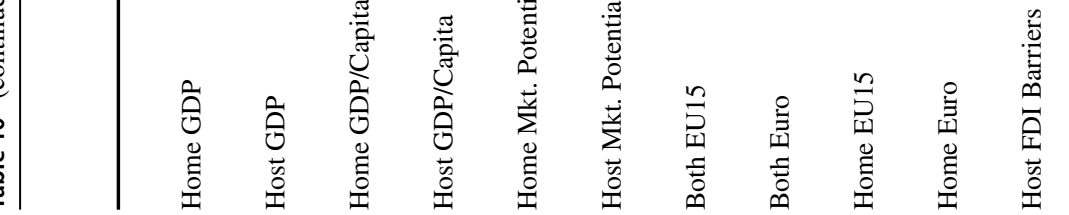




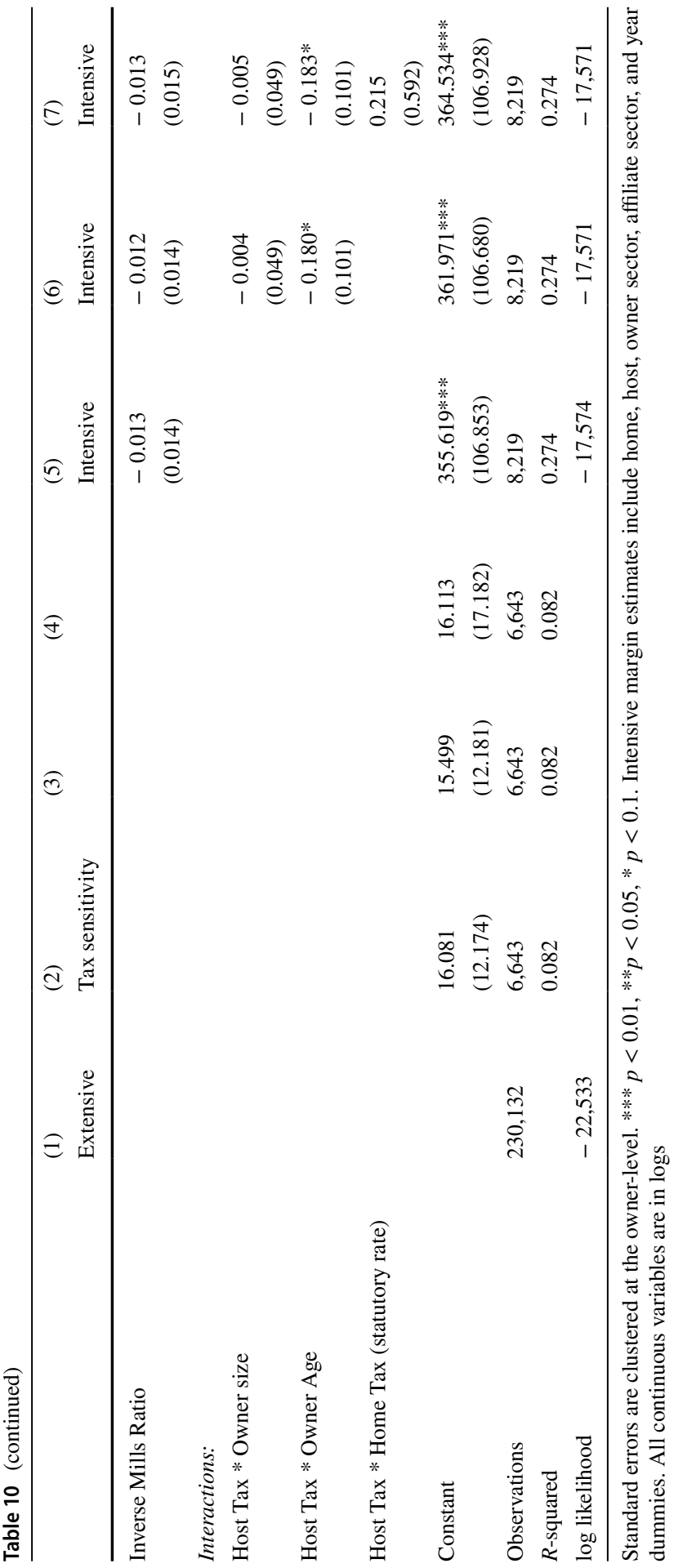


operating at the minimum efficient scale in accordance with the theory of Hartman (1985). One additional implication of this has to do with a nation's vulnerability to short-run economic shocks such as the 2020 novel coronavirus. If firms-including multinationals - are more quick to respond in intensive rather than extensive changes, then a nation may find itself more resilient if it hosts more stages of global supply chains. As such, there may be a rationale for using tax policy to attract more multinationals even if the initial size of those affiliates is small.

\section{References}

Barrios, S., Huizinga, H., Laeven, L., \& Nicodeme, G. (2012). International taxation and multinational firm location decisions. Journal of Public Economics, 96(11), 946-958.

Basile, R., Castellani, D., \& Zanfei, A. (2008). Location choices of multinational firms in Europe: The role of EU cohesion policy. Journal of International Economics, 74(2), 328-340.

Behrendt, S., \& Wamser, G. (2018). Tax-response heterogeneity and the effects of double taxation treaties on the location choices of multinational firms, CESifo Working Paper 6969.

Blonigen, B., Davies, R., Waddell, G., \& Naughton, H. (2007). FDI in space: Spatial autoregressive relationships in foreign direct investment. European Economic Review, 51(5), 1303-1325.

Blonigen, B., \& Piger, J. (2014). Determinants of foreign direct investment. Canadian Journal of Economics, 47(3), 775-812.

Brülhart, M., Jametti, M., \& Schmidheiny, K. (2012). Do agglomeration economies reduce the sensitivity of firm location to tax differentials? The Economic Journal, 122(563), 1069-1093.

Buettner, T., \& Ruf, M. (2007). Tax incentives and the location of FDI: Evidence from a panel of German multinationals. International Tax and Public Finance, 14(2), 151-164.

Chen, M., \& Moore, M. O. (2010). Location decision of heterogeneous multinational firms. Journal of International Economics, 80(2), 188-199.

Crozet, M., Mayer, T., \& Muchielli, J. L. (2004). How do firms agglomerate? A study of FDI in France. Regional Science and Urban Economics, 34(1), 27-54.

Davies, R., \& Eckel, C. (2010). Tax competition for heterogeneous firms with endogenous entry. American Economic Journal: Economic Policy, 2(1), 77-102.

Davies, R., \& Killeen, N. (2018). Location decisions of non-bank financial foreign direct investment: Firm-level evidence from Europe. Review of International Economics, 26, 378-403.

Davies, R., \& Kristjánsdóttir, H. (2010). Fixed costs, foreign direct investment, and gravity with zeros. Review of International Economics, 18(1), 47-62.

Davies, R., Norbäck, P. J., \& Tekin-Koru, A. (2009). The effect of tax treaties on multinational firms: New evidence from microdata. World Economy, 32(1), 77-110.

Davies, R., Martin, J., Parenti, M., \& Toubal, F. (2018). Knocking on tax haven's door: Multinational firms and transfer pricing. The Review of Economics and Statistics, 100(1), 120-134.

de Mooij, R., \& Ederveen, S. (2008). Corporate tax elasticities: A reader's guide to empirical findings. Oxford Review of Economic Policy, 24(4), 680-697.

Devereux, M., Elschner, C., Endres, D., \& Spengel, C. (2010). Effective tax levels using the Devereux/ Griffith methodology: Project for the EU Commission TAxUD/2008/CC/099. Brussels: European Commission.

Devereux, M., \& Griffith, R. (1998). The taxation of discrete investment choices. IFS Working Paper W98/16.

Devereux, M., \& Griffith, R. (2003). Evaluating tax policy for location decisions. International Tax and Public Finance, 10(2), 107-26.

Dubin, J., \& McFadden, D. (1984). An econometric analysis of residential electric appliance holdings and consumption. Econometrica, 52(2), 345-362.

Egger, P., \& Merlo, V. (2011). Statutory corporate tax rates and double-taxation treaties as determinants of multinational firm activity. FinanzArchiv / Public Finance Analysis, 67(2), 145-170.

Fontagné, L., \& Mayer, T. (2005). Determinants of location choices by multinational firms: A review of the current state of knowledge. Applied Economics Quarterly, 51(Suppl.), 9-34. 
Freund, C., \& Pierola, M. D. (2015). Export Superstars. The Review of Economics and Statistics, 97(5), $1023-1032$.

Fuest, C., Huber, B., \& Mintz, J. (2005). Capital mobility and tax competition. Foundations and Trends in Microeconomics, 1(1), 1-62.

Görg, H., \& Strobl, E. (2015). Does corporate taxation deter multinationals? Evidence from a historic event in Ireland. The World Economy, 38(5), 788-804.

Graham, J. (2000). How big are the tax benefits of debt? The Journal of Finance, 55(5), 1901-1941.

Gresik, T. (2001). The taxing task of taxing transnationals. Journal of Economic Literature, 39(3), 800-838.

Hartman, D. (1985). Tax policy and foreign direct investment. Journal of Public Economics, 26, 107-121.

Haufler, A., \& Wooton, I. (1999). Country size and tax competition for foreign direct investment. Journal of Public Economics, 71(1), 121-139.

Head, K., \& Mayer, T. (2004). Market potential and the location of Japanese investment in the European Union. Review of Economics and Statistics, 86(4), 959-972.

Head, K., Reis, J., \& Swenson, D. (1995). Agglomeration benefits and location choice: Evidence from Japanese manufacturing investments in the United States. Journal of International Economics, $38(3 / 4), 223-247$.

Hebous, S., Ruf, M., \& Weichenrieder, A. J. (2011). The effects of taxation on the location decision of multinational firms: M\&A versus greenfield investments. National Tax Journal, 64(3), 817-38.

Helpman, E., Melitz, M., \& Yeaple, S. (2004). Export versus FDI with heterogeneous firms. American Economic Review, 94(1), 300-316.

Hines, J. R. (1996). Altered states: Taxes and the location of foreign direct investment in America. American Economic Review, 86(5), 1076-1094.

Krautheim, S., \& Schmidt-Eisenlohr, T. (2011). Heterogeneous firms, 'profit shifting' FDI and international tax competition. Journal of Public Economics, 95(1), 122-133.

Lawless, M., McCoy, D., Morgenroth, E., \& O'Toole, C. (2018). Corporate tax and location choice for multinational firms. Applied Economics, 50(26), 2920-2931.

Markusen, J. (1984). Multinationals, multi-plant economies, and the gains from trade. Journal of International Economics, 16(3/4), 205-26.

McFadden, D. (1974). The measurement of urban travel demand. Journal of Urban Economics, 3(4), 303-328.

McFadden, D., \& Train, K. (2000). Mixed MNL models for discrete response. Journal of Applied Econometrics, 15(5), 447-470.

Merlo, V., Riedel, N., \& Wamser, G. (2016). The impact of thin capitalization rules on the location of multinational firms' foreign affiliates. Research School of International Taxation Working Paper No. 1, Universitat Tubingen.

Merz, J., Overesch, M., \& Wamser, G. (2017). Tax vs. regulation policy and the location of financial sector FDI. Journal of Banking and Finance, 78, 14-26.

Kalemli-Ozcan, S., Sorensen, B., Villegas-Sanchez, C., Volosovych, V., \& S. Yesiltas (2019). How to construct nationally representative firm-level data from the ORBIS Global Database. NBER Working Paper No. 21558.

Santos Silva, J. M. C., \& Tenreyro, S. (2006). The log of gravity. The Review of Economics and Statistics, 88(4), 641-658.

Siedschlag, I., Smith, D., Turcu, C., \& Zhang, X. (2013a). What determines the location choice of R\&D activities by multinational firms? Research Policy, 42(8), 1420-1430.

Siedschlag, I., Zhang, X., \& Smith, D. (2013b). What determines the location choice of multinational firms in the information and communication technologies sector? Economics of Innovation and New Technology, 22(6), 581-600.

Spengel, C., Endres, D., Finke, K., \& Heckemeyer, J. (2014). Effective tax levels using the Devereux/ Griffith methodology. GIZ Report. TAXUD/2013/CC/120.

Tirole, J. (1988). The theory of industrial organization. Cambridge: The MIT Press.

Voget, J. (2015). The effect of taxes on foreign direct investment: A survey of the empirical evidence. ETPF Policy Paper 3.

Wilson, J. D. (1986). A theory of interregional tax competition. Journal of Urban Economics, 19, 296-315.

Yeaple, S. (2009). Firm heterogeneity and the structure of U.S. multinational activity. Journal of International Economics, 78(2), 206-215. 
Zodrow, G. R., \& Mieszkowski, P. (1986). Pigou, Tiebout, Property Taxation, and the Underprovision of Public Goods. Journal of Urban Economics, 19, 356-370.

Publisher's Note Springer Nature remains neutral with regard to jurisdictional claims in published maps and institutional affiliations.

\section{Affiliations}

\section{Ronald B. Davies $^{1,2,3} \cdot$ lulia Siedschlag ${ }^{4,5}$ ([) $\cdot$ Zuzanna Studnicka'}

1 University College Dublin, Dublin, Ireland

2 Oxford University Centre for Business Taxation, Oxford, UK

3 CES-Ifö, Munich, Germany

4 Economic and Social Research Institute, Dublin, Ireland

5 Department of Economics, Trinity College Dublin, Dublin, Ireland 